\title{
Community stability within the St. Marys River fish community: evidence from trawl surveys
}

By

\author{
Jeffrey S. Schaeffer ${ }^{{ }^{*}}$, Anjanette K. Bowen ${ }^{\mathrm{b}}$, David G. Fielder ${ }^{\mathrm{c}}$
}

${ }^{\mathrm{a} U}$. S. Geological Survey Great Lakes Science Center

1451 Green Road

Ann Arbor, MI 48105

${ }^{\mathrm{b} 2} \mathrm{U}$. S. Fish and Wildlife Service

Alpena Fish and Wildlife Conservation Office

480 W. Fletcher Street

Alpena, MI 49707

${ }^{\mathrm{c}}$ Michigan Department of Natural Resources

Alpena Fisheries Research Station

160 E. Fletcher Street

Alpena, MI 49707

*Corresponding author; jschaeffer@usgs.gov; voice 1-734-214-7250 
Abstract- A trawl survey was conducted in the Saint Marys River during 2010-2011 and compared to a prior trawl survey conducted during 1979-1983 to look for long-term changes in the fish community, especially in terms of changes induced by invasive species. We found no substantive temporal differences in fish density, fish biomass, or fish diversity; lower trawl biomass during 2010-2011 was likely a result of day versus night trawling. The Saint Marys River remains a center of high fish diversity, invasive species remain rare, and the system continues to exhibit overall long-term stability. Trawling captured a wide range of fish species, but was likely not an effective stock assessment tool for managed game fish because catch rates were low or variable for all game species except yellow perch. Trawling appeared to be an effective tool for sampling connecting channel diversity, especially when large numbers of individuals are needed for directed studies, but annual sampling would be needed to use data to assess recruitment.

Key words: St. Marys River, biodiversity, non-game fishes, trawl survey 


\section{Introduction}

Great Lakes connecting channels are among the largest rivers on earth in terms of flow and are centers for both regional biodiversity and fishing (Hondorp et al. 2014). A growing body of evidence suggests that conditions in connecting channels have direct effects on main-lake fish communities, especially in terms of spawning habitat and dispersal of recruits (Brodnik et al. 2016, DuFour et al 2016); Thus, health and stability of connecting channel fish communities are of great interest to resource managers for both the connecting channels proper and their lakes. But, fisheries assessments that allow insight into connecting channel community trends are infrequent; therefore, managers often rely on data comparisons that are isolated temporally, spatially, or collected using different methods. This is especially true for the St. Marys River (SMR), a 112-km river that connects Lake Superior with Lake Huron.

The SMR is managed as a distinct international system by neighboring countries with regional coordination by the Great Lakes Fishery Commission's Lake Huron Committee (LHC) (Fielder 2002a); regulations and assessments along the river vary according to varied management authorities. The only comprehensive river-wide assessment is a periodic open-water gill net survey conducted by the international LHC's St. Marys River Fishery Task Group (SMRFTG) and supplemented by spatially fragmented creel surveys. Data from those surveys suggest long-term stability within the fish community (Schaeffer et al. 2011) and that periodic gill net surveys are adequate to assess adult fish diversity. But, they are insufficient for stock assessments (Schaeffer et al. 2011, Schaeffer et al. 2014). Furthermore, existing surveys focus exclusively on adult fish, thus, knowledge about trends in the juvenile prey fish community is lacking, and scarcity of those data has 
been identified as an important missing component needed for effective fisheries management (Gebhardt et al. 2002, Pratt and O'Connor 2011, Schaeffer et al. 2011). Managers wanted to know if apparent fish community stability observed in the periodic gillnet surveys that sample predators and adult fish is also evident in the prey juvenile/prey fish community.

The only SMR quantitative historical data that exist are from a night trawl survey conducted during 1979-1983 as part of an environmental impact assessment for proposed winter navigation (Liston et al. 1986). Ten trawl tows were conducted as a pilot study during 1979, and then a full study consisting of monthly night trawling was conducted May through November of 1982 and 1983 that resulted in 111 tows in total (hereafter referred to as the Liston Survey). The Liston Survey suggested that the SMR nearshore community was diverse and dominated by native species with relatively few invasive species. Their 1979-1983 results were compared with results of an electrofishing survey taken during 2006-2008 by Pratt and O'Connor (2011) who, while acknowledging that direct comparisons were not possible due to gear and location differences, concluded that the nearshore fish community had not changed appreciably over 23 years. However, while the electrofishing survey did a thorough job of documenting nearshore diversity, it was different enough from the Liston survey in that some uncertainty regarding mainchannel trends remained among resource managers, and especially among those concerned with invasives. One key species of interest was the invasive round goby Neogobious melanostomus that had been documented sporadically from the SMR, but was not sampled via the electrofishing survey. Because round gobies reduce nearshore 
fish diversity in the Great Lakes (Poos et al. 2010), knowledge of their abundance within the SMR was considered important. However, their absence from the electrofishing survey was equivocal because it could have resulted from either true low abundance or low catchability.

During 2010-2011, support from the Great Lakes Restoration Initiative (GLRI) made it possible to re-survey the SMR using the same trawl used in the Liston Survey. The primary survey objective was to attempt to replicate the original Liston Survey with an identical trawl at the same channel sampling locations. Additional data at eleven other locations near periodic gill net assessments conducted by the SMRFTG would expand spatial coverage among different habitats not sampled by the Liston Survey, and sample gill net locations to capture juvenile and prey species not well represented during that survey.

The Liston Survey could not be replicated fully for three reasons: 1) current agency safety protocols allowed small-vessel trawling during the day, but not at night, 2) lower water levels during 2010-2011 did not allow the exact Liston trawl locations to be sampled because sites were much shallower than during 1979-1983, and 3) funding was sufficient to sample during late August-early September only, but not monthly during May-November as was done by Liston et al. (1986) . However, adjacent sites in close proximity could be sampled, and the day trawling was consistent with U.S. Fish and Wildlife Service aquatic invasive species surveillance protocols, which in the Great Lakes rely heavily on day trawling using small vessels (Schaeffer et al. 2005). 
We present results of a day trawl survey conducted during 2010-2011, and compare findings directly with the Liston night trawl survey. We also compare results qualitatively with gill net assessments (Schaeffer et al. 2011) and the electrofishing survey conducted by Pratt and O'Connor (2011). We discuss what those surveys tell us about the SMR nearshore fish community, and offer suggestions on how to move forward with future nearshore fish community assessments.

Methods

Site selection and description- Sampling locations (Figure 1) were chosen based on 18 trawl site recommendations identified in the St. Marys River Fisheries Assessment Plan (SMRFTG 2002, Great Lakes Fishery Commission 2016) and included seven sites originally surveyed by Liston et al. (1986) in both U.S. and Canadian waters of the St. Marys River. Eleven additional locations were added to provide more comprehensive spatial coverage in habitats proximate to on-going SMRFTG gill net assessments (which had been located based on habitat). Sampled sites included channels of the St. Marys River, embayments, and tributary mouths. Sites included both submerged vegetated or non-vegetated habitats over sand, clay, or small cobble substrates.

Field methods- Sampling took place during late August or early September during 20102011 so that age- 0 fish were recruited fully to the gear. We conducted daytime trawl tows with a $4.9 \mathrm{~m}$ small mesh, semi-balloon bottom trawl $(3.8 \mathrm{~cm}$ stretch mesh body, $0.8 \mathrm{~mm}$ stretch -mesh cod end). Each sample consisted of one 5-minute trawl tow conducted along a depth contour at a speed of $4 \mathrm{~km} /$ hour. Up to four $1.5 \mathrm{~m}$ depth contours were 
sampled (1.5-3.0 m, 3.1-4.5 m, 4.6-6.1 $\mathrm{m}$ and 6.1-7.6 $\mathrm{m}$ contours) when available. At any given location, one to four trawl tows were conducted depending on the depth and trawl lane availability. Although we used the same trawl and tow times used by the Liston Survey, we did not know the original speed at which they towed their gear. We chose speeds that optimized trawl performance in terms of correct net deployment, reasoning that Liston et al. (1986) would have chosen similar speeds to optimize their identical trawl. Water depth $(\mathrm{m})$, surface and bottom water temperature $\left({ }^{\circ} \mathrm{C}\right)$, and GPS coordinates were recorded at the beginning and end of each trawl tow. Catches were bagged and frozen for later processing.

Laboratory methods- Catches were later thawed, all fish were identified to species whenever possible, counted, and each species was weighed (g) in aggregate. In a few cases, large numbers of small minnows were captured that could not be identified easily. In those cases, a random subsample was taken for detailed identification and proportions of individual species were apportioned to the catch. We also measured individual lengths $(\mathrm{mm})$ and weights $(\mathrm{g})$ from a random sample of up to 50 individuals from each species from each tow.

Analytical methods- We were able to make direct comparisons with the 1982-1983 Liston trawl data because counts and weights of each species from individual trawl tows were available as appendices within Liston et al. (1986), with the understanding that we were comparing day versus night data and differences in catchability were likely. Catch data from Liston et al. (1986) were transcribed into an electronic database structured 
identically to our trawl data. We excluded the 1979 Liston data because it had only 10 tows and did not include aggregate weights. We assessed differences in CPE and biomass among surveys using non-parametric Kruskal-Wallis tests because distributions indicated serious violations of normality and homogeneity. We used probability of a Type-1 error of alpha $=0.05$ for our significance level in statistical testing and followed the methods of Sokal and Rohlf (1981). Analysis was performed with SAS 9.4 computer software (SAS, 2012).

Results and Discussion

The 1982-83 Liston Survey captured 25,109 fish representing 36 species during 111 night tows while the 2010-2011 GLRI survey captured 28,073 fish representing 33 species using day trawl tows (Table 1). Forty two identified species were collected among the two trawl surveys. Twenty four species were common to both surveys, while 19 species were captured in one survey, but not the other.

The Liston survey collected 11 species not captured by the GLRI survey (Table 1). The GLRI survey did not capture gizzard shad Dorosoma cepedianum, a southern species, which is so rare in the SMR that its absence might be expected even with substantial sampling effort. It also did not capture cisco Coregonus artdedii, lake whitefish Coregonus clupeaformis, round whitefish Prosopium cylindraceum, Chinook salmon Oncorhynchus tshawytscha, or burbot Lota lota. All are coolwater species (Scott and Crossman 1973), and would be less likely to be encountered in the GLRI AugustSeptember survey compared to the Liston May-November survey that likely sampled in 
colder conditions. The GLRI survey also did not capture any common carp Cyprinus carpio, silver redhorse Moxostoma anisurum, shorthead redhorse Moxostoma macrolepidotum, slimy sculpin Cottus cognatus, or spoonhead sculpin Cottus ricei. Those species were captured in the Liston survey, but are benthic species that may have been more susceptible to night trawling (Yule et al. 2011). However, there were no abundant species sampled during 1982-83 missing during 2010-2011; each species captured in the Liston survey only was represented by less than 10 individual captures in their 111 trawl tows.

The GLRI survey captured eight species not found in the Liston Survey (Table 1). Both threespine sticklebacks Gasterosteus aculeatus and round goby were recent invaders and were unlikely to be present during the 1982-83 Liston survey (Jude et al. 1992, Stedman and Bowen 1985). The GLRI survey captured largemouth bass Micropterus salmoides, golden shiners Notemigonus chrysoleucas, common shiners Luxilus cornutus, and both blackchin Notropis heterolepis and blacknose shiners Notropis heterodon that were not captured during the Liston Survey. New species caught during 2010-2011 were represented by no more than 99 individual captures in 121 trawl tows, including all the new invasives.

Both trawl CPE distributions (fish per 5 minute tow) and biomass differed among surveys (Kruskal-Wallis, two tests, $\mathrm{P}<0.05$ ). The GLRI survey had a higher frequency of large catches, while the Liston Survey had higher frequency of large biomass (Figure 2). This 
likely occurred because the Liston night trawling captured higher numbers of benthic species that were either less common or not captured during GLRI day trawling.

For some prevalent species, we observed more than ten-fold differences in mean CPE between time periods (e.g. trout-perch Percopsis omiscomayus andrainbow smelt Osmerus mordax) (Table 1). However, we ascribed little meaning to among-survey differences in abundance for individual species. While no individual size data were available from the Liston Survey, data from the GLRI survey indicated that most captured fish were less than $80 \mathrm{~mm}$ TL (mm) (Figure 3) and many could have been age- 0 recruits. For many species, survey data likely represented snapshots of recruitment separated by 26 to 28 years with no data, and no information on among-year variability in age- 0 abundance. Thus, temporal differences should not be interpreted as end-members of any temporal trend.

The GLRI survey re-sampled the SMR near Liston sites, but also sites adjacent to SMRFTG fixed gillnet locations (Schaeffer et al. 2011). CPE and biomass distributions differed among Liston and SMRFTG locations (Kruskal-Wallis, two tests, $\mathrm{P}<0.05$ ), with the SMRFTG sites having higher frequency of large catches and heavier biomass (Figure 4) possibly because SMRFTG sites represented broader habitat diversity. SMRFTG sites also had more species (31) than Liston sites (23), but that likely occurred because of greater numbers of SMRFTG stations (seven vs eleven stations). However, it does suggest that choice of trawl sites would be important if the survey were expanded into an annual monitoring effort. 
One additional goal of the GLRI trawl survey was to determine if it could support future stock assessments. The SMR has four primary managed target species: cisco, northern pike Esox lucius, walleye Sander vitreus, and yellow perch Perca flavescens. Of those, only yellow perch were captured at CPEs $>0.1$ fish per tow (Table 1 ). There were no differences in yellow perch CPE distributions among years (Kruskal-Wallis test, $\mathrm{P}<0.05$ ), and overall mean yellow perch CPE was 20.1 fish per tow and 2,2078 individuals were captured over two years. Length frequency distributions suggest that yellow perch were fully recruited to the trawl at lengths exceeding $30 \mathrm{~mm}$ (Figure 5). However, apparent high catchability of both age- 0 and older fish are only prerequisites for a stock assessment because gill net surveys in the SMR occur only about every 4 to 6 years, and the temporal gaps are large enough to allow individual year classes to pass through the population completely without detection (Schaeffer et al. 2011). A robust stock assessment would require annual sampling for several years with both gears to both establish a recruitment index and track growth and survival of individual year classes.

Most of our analyses were contingent on comparisons of day versus night trawling, and assumed equal diel catchability. That assumption was likely violated because prior studies have found higher biomass in night trawl catches versus day sampling, especially for benthic species such as slimy sculpin, spoonhead sculpin, trout-perch, and burbot (Yule et al. 2011). Kocovsky et al. (2011) also found higher night catchability for yellow perch, white perch, and trout-perch in Lake Erie during clear conditions associated with dreissenid mussels. Thus, wherever diel catchability data existed for species captured in 
the SMR surveys, data suggested consistently that night trawling would have been more efficient. This could have reduced biomass differences among surveys, but could have increased CPE differences beyond the higher frequency of larger catches in the GLRI survey. Diel catchability differences would be unlikely to alter our conclusion that diversity has remained high in the SMR, because that conclusion was based on simple presence/absence. There, a single capture would verify presence and diel catchability differences would have to be substantial to have not captured a single individual in over 111 trawl tows, although that may have actually occurred with common carp and redhorses.

Our research had generally similar findings to both long-term gill net assessments and a recent electrofishing survey on the SMR. Schaeffer et al. (2011) suggested that gill net assessments revealed long-term stability within the open-water fish community, while Pratt and O'Connor (2011) reached similar conclusions about long term stability by comparing an electrofishing survey during 2006-2008 with trawl data from the Liston Survey (Liston et al. 1986). They found low abundance of invasives, and viewed the native fish community as complex, diverse, and healthy. However, there were some differences between their work and ours. Pratt and O'Connor (2011) captured more species than we did (46 versus 31), likely because their survey was stratified among distinct habitats, while ours focused on sampling stations that had been sampled previously and we had little or no information on among station habitat differences. Their survey also took place during May-June, a time period when electrofishing is an effective 
tool for assessing Great Lakes nearshore diversity (Ross 2013), but when water temperatures were likely lower than during the GLRI survey.

Overall, we share the view that the SMR remains a healthy, diverse community with low invasive abundance, but note one potential positive change. We collected both blacknose and blackchin shiners in our survey. Over the two year study, some individuals of each species were collected at almost every one of our stations. Pratt and O'Connor (2011) collected blacknose shiners only, while the Liston Survey did not find either species. Both are considered to be key indicators of pristine conditions because they require exceptionally clear water and dense aquatic vegetation, with the blackchin shiner being so sensitive to perturbations that may have extirpated the species from Lake Erie prior to 1900 (Trautman 1981). While their recent presence may indicate actual improvement in habitat or water quality, they can have very localized distributions and are therefore hard to detect (Burr et al. 2005). Regardless, their presence in the SMR is strong evidence of overall system health.

One of the underlying reasons for our survey was concern among managers that electrofishing might not detect invaders, particularly round goby. This turned out to be unwarranted because we captured few round gobies as well. They appear to have not proliferated in SMR as they have done elsewhere in the Great Lakes, which may be one reason why nearshore diversity remains high. A recent study by Brandner et al. (2013) suggests that electrofishing is an effective sampling tool for round goby, thus, low catches in both recent SMR surveys likely reflected low abundance and not low 
catchability, although we note that trawling is precluded in their preferred rocky habitats which could have been under-sampled. The same appears to be true for three-spined sticklebacks that were also captured in low numbers by both surveys, although they were confined to main river sites in the electrofishing survey (Pratt and O'Connor 2011).

The SMR appears to be exhibiting resiliency to invasive species that have plagued other areas of Lakes Superior and Huron. Similar to the round goby's failure to become highly abundant, white perch (another invasive) has remained at low abundance in the SMR. Eurasian ruffe also appears to have skipped the SMR in its spread between the lakes. Except for sea lamprey, the diversity and health of the SMR ecosystem may illustrate that invasive species may be best resisted in the Great Lakes by conserving diverse native species assemblages through protection of habitats and ecosystem processes.

In the SMR, three different surveys performed using different gears all found high diversity and no substantive changes in species composition. There was also no apparent change in abundance, although comparisons were extremely limited due to differences in sampling design and high variability in catches within each survey. This suggests either trawling or electrofishing would be an effective tool for monitoring this fish community. Electrofishing conveys more information about fish-habitat relationships at finer spatial scale, while trawling appears to capture larger numbers of rare cyprinids, yellow perch, and possibly other species for directed studies. But either method would be useful in assessing overall fish community trends, with greatest utility coming from annual assessments. 


\section{Acknowledgements}

We acknowledge the members of the St. Marys River Fishery Task Group for their support. We also thank those who assisted with sampling or sample processing including: T. Somers, L. O'Connor, A. Chambers, J. Sauve, J. Gostiaux, T. Radka, J. Salvin, K. Perrault, J. Gerbyshak, C. Lepper, and H. Rawlings. This project was funded by the Great Lakes Restoration Initiative. D. Warner and two anonymous reviewers provided constructive reviews on earlier versions of the manuscript. Authorized by the Director, U.S. Geological Survey. 


\section{Literature Cited}

Bradner, J., Pander, J., Mueller, M., Cerwenka, A.F., Geist, J. 2013. Effects of sampling techniques on population assessment of invasive round goby Neogobius melanostomus. J Fish Biol. 82 (2013), pp.2063-79.

Brodnik, R.M., Fraker, M.E., Anderson, J., Carreon-Martinez, L., DeVanna, K.M., Heath, D.D., Reichert, J.M., Roseman, E.F., Ludsion, S.A. 2016. Larval dispersal underlies demographically importantintersystem connectivity in a Great Lakes yellow perch (Perca flavescens) population. Can. J. Fish. Aquat. Sci. 73 (2016), pp. 1-11.

Burr, B.M., Santucci, V.J., Roberts, M.E., Davis, A.M., Whiles, M.R., 2005. Conservation status and life history characteristics of the blacknose shiner, Notropis heterolepis, (Cyprinidae), and blackchin shiner, Notropis heterodon (Cyprinidae), with conservation evaluations of the pugnose shiner, Notropis anogenus (Cyprinidae), and banded killifish Fundulus diaphanous (Fundulidae). Max McGraw Wildlife Foundation, Final Report.

DuFour, M. R., May C. J., Roseman E. F., Ludsin S. A., Vandergoot C. S., Pritt J. J., Fraker M. E., Davis J. J., Tyson J. T., Miner J. G., Marschall E. A., and Mayer C. M.. 2015. Portfolio theory as a management tool to guide conservation and restoration of multistock fish populations. Ecosphere 6 (2015), pp.296.

Fielder, D.G., 2002a. St. Marys River Task Group: The St. Marys River and Challenges of Multijurisdictional Fisheries-Eight governmental agencies possess varying degrees of management. Fisheries 27 (2002), pp., 32-34. 
Fielder, D.G.,2002b. Sources of walleye recruitment in Saginaw Bay, Lake Huron and recommendations for further rehabilitation. Michigan Department of Natural Resources, Fisheries Division Research Report, p. 2062.

Fielder, D.G., Borgeson, D.J., Bowen, A.K., Koproski, S.R., Greenwood, S. J., Wright, G.M., 2003. Population dynamics of the St. Marys River fish community 1975-2002. Great Lakes Fishery Commission, Miscellaneous publication. http://www.glfc.org/lakecom/lhc/SMR2002rpt.pdf. Ann Arbor.

Fielder, D.G, Liskauskas, A., Mohr, L., Boase, J., 2008. Nearshore Fish Community, In: Bence, J.R., Mohr, L.C. (Eds.), The state of Lake Huron in 2004. Great Lakes Fisheries Commission Special Publication 08-01, pp. 42-51.

Fielder, D.G., Thomas, M.V., 2006. Fish Population Dynamics of Saginaw Bay, Lake Huron 1998-2004. Michigan Department of Natural Resources, Fisheries Division Research Report, p.2083.

Fielder, D.G., Waybrant, J.R., 1998. Fish Population Surveys of St. Marys River, 1975-95, and Recommendations for Management. Michigan Department of Natural Resources, Fisheries Division Research Report, p. 2048.

Gebhardt, K., Fielder, D.G., Greenwood, S., Robbins, H., Sutton, T., 2002. St. Marys River Fisheries Assessment Plan. Great Lakes Fisheries Commission, Miscellaneous publication. http://www.glfc.org/lakecom/lhc/smrfinal.pdf. Ann Arbor. 
Great Lakes Fishery Commission. 2016. Lake Huron Committee- St. Marys River Task Grout. Available at http://glfc.org/lakecom/lhc/SMRFTG.php, accessed 12/31/15).

Hondorp, D.W., Roseman, E.F., Manny, B. 2014. An ecological basis for future fish habitat restoration in the Huron-Erie Corridor. J.Great Lakes Res. Supplement 40 (2014), pp.2330.

Jude D.J., Reider R.H., Smith G.R.,. 1992. Establishment of Gobiidae in the Great Lakes basin. Can. J. Fish. Aquat. Sci. 49 (1992), pp. 416-421

Liston, C.R., McNabb, C.D., Brazo, D., Bohr, J., Crag, J., Duffy, W., Fleischer, G., Knoecklein, G., Koehler, F., Ligman, R., O'Neal, R., Siamij, M., Roettger, P.P., 1986. Limnological and fisheries studies in relation to proposed extension of the navigation season, 19821983. U.S. Fish and Wildlife Service FWS/OBS-80/62.3.

Poos, M., Dexstrase, A.J., Schwalb, A.N., Ackerman, J.D., 2010. Secondary invasion of the round goby into high diversity Great Lakes tributaries and species at risk hotspots: potential new concerns for endangered freshwater species. Biol. Invasions 12 (2010), pp. $1269-1284$.

Pratt, T.C., O’Connor, L.M., 2011. An assessment of the heath and historical changes of the nearshore fish community of the St. Marys River. J. Great Lakes Res. 37 (2011), pp. 6169.

Ross, J. 2013. A Coastal Monitoring Program for a Large Lake Fish Community: The First Step in Capturing Long-term Trends and Addressing Evolving Questions. MS Thesis, University of Toledo. 
SAS Institute, Inc. 2012. OnlineDoc 9.1.2. Cary, NC, SAS Institute, Inc.

Schaeffer, J.S., Bowen, A., Thomas, M., French III, J.R.P., Curtis, G.L. 2005. Invasion history, proliferation, and offshore diet of the round goby Neogobius melanostomus in western lake Huron, USA. J. Great Lakes Res. 31 (2005), pp. 414-425.

Schaeffer, J.S., Fielder, D.G., Godby, N., Bowen, A., O’Connor, L., Parrish, J., Greenwood, S., Chong, S., Wright, G., 2011. Long-term trends in the St. Marys River open water fish community. J. Great Lakes Res. 37 (Supplement 2) (2011), pp. 70-79.

Schaeffer, J.S., Rogers, M.W., Fielder, D.G., Godby, N., Bowen, A., O'Connor, L., Parrish, J., Greenwood, S., Chong, S., Wright, G. 2014. Designing long-term fish community assessments in connecting channels: lessons from the Saint Marys River. J. Great Lakes Res. 40 (2014), pp. 15-22.

Scott, W. B., Crossman, E.J. 1973. Freshwater Fishes of Canada. Bull. Fish. Res. Board Can. 184.

Sokal, R. R., Rohlf, F.J., 1981. Biometry, second ed. W. H. Freeman and Company, San Francisco, California.

Stapanian, M.A., Kocovsky, P.M., Adams, J.V. 2009. Change in diel catchability of young of the year yellow perch associated with dreissenid mussels. Freshwater Biology 54 (2009), pp. 1593-1604. 
Stedman, R.M., Bowen, C. A. 1985. Introduction and spread of the threespine stickleback (Gasterosteus aculeatus) in Lakes Huron and Michigan. Journal of the Great Lakes Research 11 (1985), pp. 508-511.

Trautman, M. B.,1981. The fishes of Ohio. The Ohio State University Press, Columbus, Ohio.

Yule, D. L., Adams, J. V., Stockwell, J. D., Gorman, O. T. 2008. Factors affecting bottom trawl catches: implications for monitoring the fishes of lake Superior, N. Am. J. Fish. Manage., 28 (2008), pp. 109-122. 
Table 1. Number captured (N),mean Trawl CPE (fish/5 min tow) and mean biomass (g) per tow of fish species captured by Liston et al. (1984) during 1982-83 and GLRI study (2010-2011) at similar sites in the St. Marys River, MI. Invasive species not present during 1982-1983 denoted by - .

\begin{tabular}{|c|c|c|c|c|c|c|}
\hline \multirow[b]{2}{*}{ Species } & \multicolumn{3}{|c|}{$1982-1983$} & \multicolumn{3}{|c|}{$2010-2011$} \\
\hline & $\mathrm{N}$ & CPE & Biomass (g) & $\mathrm{N}$ & $\mathrm{CPE}$ & Biomass (g) \\
\hline Alewife & 3 & $<0.1$ & 0.6 & 56 & 0.5 & 0.2 \\
\hline Gizzard shad $^{1}$ & 3 & $<0.1$ & 0.3 & 0 & 0 & 0 \\
\hline Rainbow smelt & 337 & 3 & 8.3 & 3085 & 25.9 & 9.1 \\
\hline Northern pike & 60 & 0.6 & 178.6 & 12 & 0.1 & 3.3 \\
\hline Brown bullhead & 23 & 0.2 & 23.6 & 29 & 0.2 & 81.6 \\
\hline Burbot $^{1}$ & 2 & $<0.1$ & 0.8 & 0 & 0 & 0 \\
\hline Brook stickleback & 128 & 3.3 & 3.2 & 1196 & 10.1 & 4.6 \\
\hline Threespine stickleback $^{2}$ & - & - & - & 99 & 0.8 & 0.2 \\
\hline Ninespine stickleback & 1783 & 16 & 17.7 & 1217 & 10.2 & 4.3 \\
\hline Trout-perch & 7351 & 65.6 & 229 & 439 & 3.7 & 11.3 \\
\hline White perch & 26 & 0.3 & 0.8 & 14 & 0.1 & 0.2 \\
\hline Cisco $^{1}$ & 3 & $<0.1$ & 0.1 & 0 & 0 & 0 \\
\hline Lake whitefish $^{1}$ & 9 & 0.1 & 3.7 & 0 & 0 & 0 \\
\hline Round whitefish ${ }^{1}$ & 3 & $<0.1$ & 2.8 & 0 & 0 & 0 \\
\hline Unidentified whitefish ${ }^{1}$ & 0 & 0 & 0 & 1 & $<0.1$ & 0.1 \\
\hline Chinook salmon $^{1}$ & 1 & $<0.1$ & 0.1 & 0 & 0 & 0 \\
\hline Common carp ${ }^{1}$ & 6 & $<0.1$ & $<0.1$ & 0 & 0 & 0 \\
\hline White sucker & 759 & 6.8 & 974.3 & 245 & 2.1 & 71.5 \\
\hline Silver redhorse ${ }^{1}$ & 1 & $<0.1$ & 13.3 & 0 & 0 & 0 \\
\hline Shorthead redhorse ${ }^{1}$ & 1 & $<0.1$ & 8.2 & 0 & 0 & 0 \\
\hline Golden shiner $^{3}$ & 0 & 0 & 0 & 2 & $<0.1$ & 0.2 \\
\hline Emerald shiner & 392 & 3.5 & 13.2 & 1426 & 12 & 50.7 \\
\hline Common shiner ${ }^{3}$ & 0 & 0 & 0 & 3 & $<0.1$ & 0.1 \\
\hline Blackchin Shiner $^{3}$ & 0 & 0 & 0 & 14 & 0.1 & $<0.1$ \\
\hline Blacknose Shiner ${ }^{3}$ & 0 & 0 & 0 & 47 & 0.4 & 0.3 \\
\hline Spottail shiner & 4017 & 35.9 & 100.9 & 1213 & 10.2 & 10.7 \\
\hline Mimic shiner ${ }^{1}$ & 2261 & 20.4 & 25.5 & 2 & $<0.1$ & $<0.1$ \\
\hline bluntnose Minnow & 143 & 1.3 & 2.4 & 1994 & 16.8 & 16 \\
\hline Cyprinid & 19 & 0.2 & 0 & 11442 & 96.1 & 86.2 \\
\hline Rock bass & 433 & 3.9 & 143 & 73 & 0.6 & 1.9 \\
\hline Pumpkinseed & 8 & $<0.1$ & 1.8 & 217 & 0.9 & 10.6 \\
\hline Bluegill & 287 & 2.6 & 1.6 & 217 & 1.8 & 1 \\
\hline Smallmouth bass & 9 & $<0.1$ & 8.9 & 25 & 0.2 & 31.8 \\
\hline Largemouth bass ${ }^{3}$ & 0 & 0 & 0 & 6 & $<0.1$ & 0.8 \\
\hline Black crappie & 323 & 2.9 & 4.9 & 2 & $<0.1$ & $<0.1$ \\
\hline lowa darter & 133 & 1.2 & 3.6 & 558 & 4.7 & 2.6 \\
\hline Johnny darter & 2576 & 23.1 & 13.3 & 546 & 4.6 & 2.2 \\
\hline Logperch & 486 & 4.4 & 17.9 & 515 & 4.3 & 8.6 \\
\hline Yellow perch & 2078 & 18.7 & 194.3 & 2390 & 20.1 & 66.7 \\
\hline Walleye & 106 & 0.9 & 130.1 & 7 & $<0.1$ & 15.9 \\
\hline Mottled sculpin & 1246 & 11.2 & 26.3 & 74 & 0.6 & 1 \\
\hline Slimy sculpin ${ }^{1}$ & 2 & $<0.1$ & $<0.1$ & 0 & 0 & 0 \\
\hline Spoonhead sculpin ${ }^{1}$ & 1 & $<0.1$ & $<0.1$ & 0 & 0 & 0 \\
\hline Round goby ${ }^{2}$ & - & - & - & 28 & 0.2 & 0.9 \\
\hline Unidentified $^{1}$ & 0 & 0 & 0 & 1 & $<0.1$ & 5.9 \\
\hline Totals & 25019 & 227.6 & 2153.7 & 28073 & 227.5 & 498.7 \\
\hline
\end{tabular}

${ }^{1}$ captured during 1982-1983 only

${ }^{2}$ Invader- not present during 1982-83 but present during 2010-2011.

${ }^{3}$ Captured during 2010-2011 only. 


\section{List of Figures}

Figure 1. Map of Saint Marys River, Michigan-Ontario, showing approximate trawl locations sampled by the Liston Survey, 1982-1983, and resampled during 2010-2011, and new additional SMRFTG trawl sites.

Figure 2. CPE (top panel) and biomass (bottom panel) of 111 trawl catches from the 1982-1983 Liston Survey, and 121 catches from the GLRI trawl survey, 2010-2011, Saint Marys River, Michigan-Ontario. Solid horizontal box lines denote median, $25^{\text {th }}$, and $75^{\text {th }}$ percentiles, while whiskers denote $10^{\text {th }}$ and $90^{\text {th }}$ percentiles. Means shown as horizontal dotted lines. Zero values on y axes offset for clarity.

Figure 3. Length frequency distributions of 8196 fish captured during 121 trawl tows on the St. Marys River, 2010-2011. Frequencies less than 5 not visible.

Figure 4. Distributions of CPE (top panel) and biomass (bottom panel) between Liston Survey trawl sites resampled by the GLRI survey during 2010-2011, and new trawl sites established near SMRFTG gill net stations, Saint Marys River, Michigan-Ontario. Solid horizontal box lines denote median, $25^{\text {th }}$, and $75^{\text {th }}$ percentiles, while whiskers denote $10^{\text {th }}$ and $90^{\text {th }}$ percentiles. Means shown as horizontal dotted lines. Zero values on y axes offset for clarity.

Figure 5. Length frequency distributions of 1,035 yellow perch Sampled during the GLRI trawl survey, Saint Marys River, 2010-2011. 


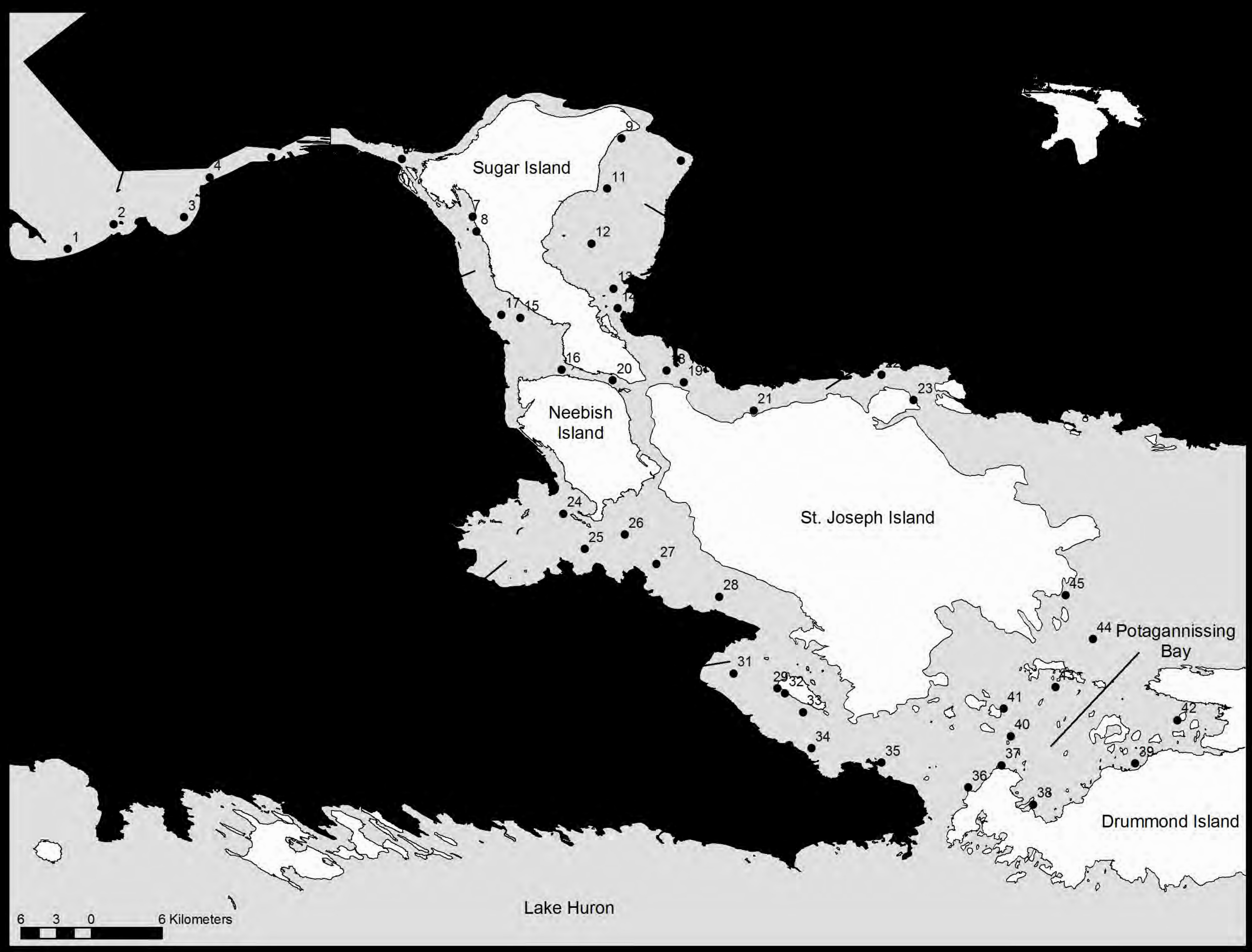




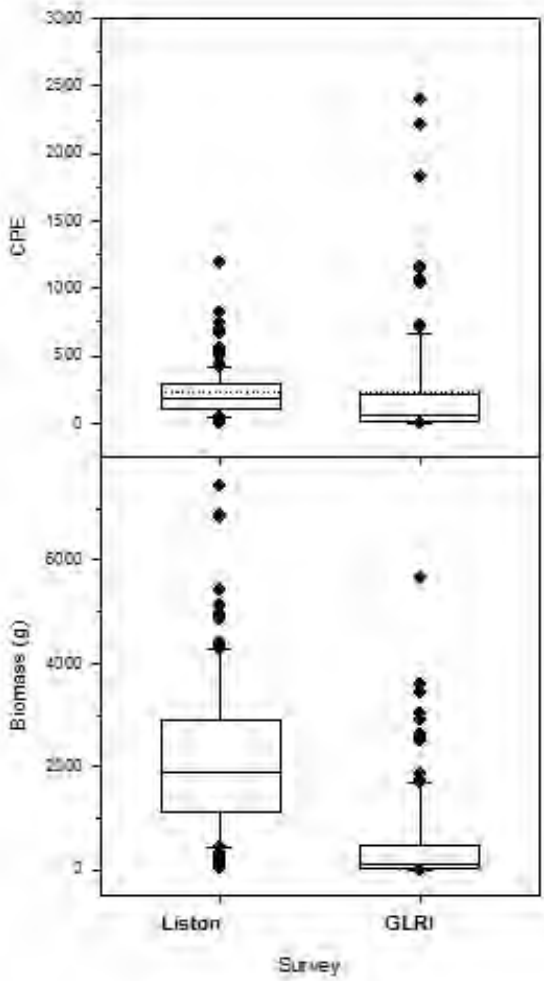




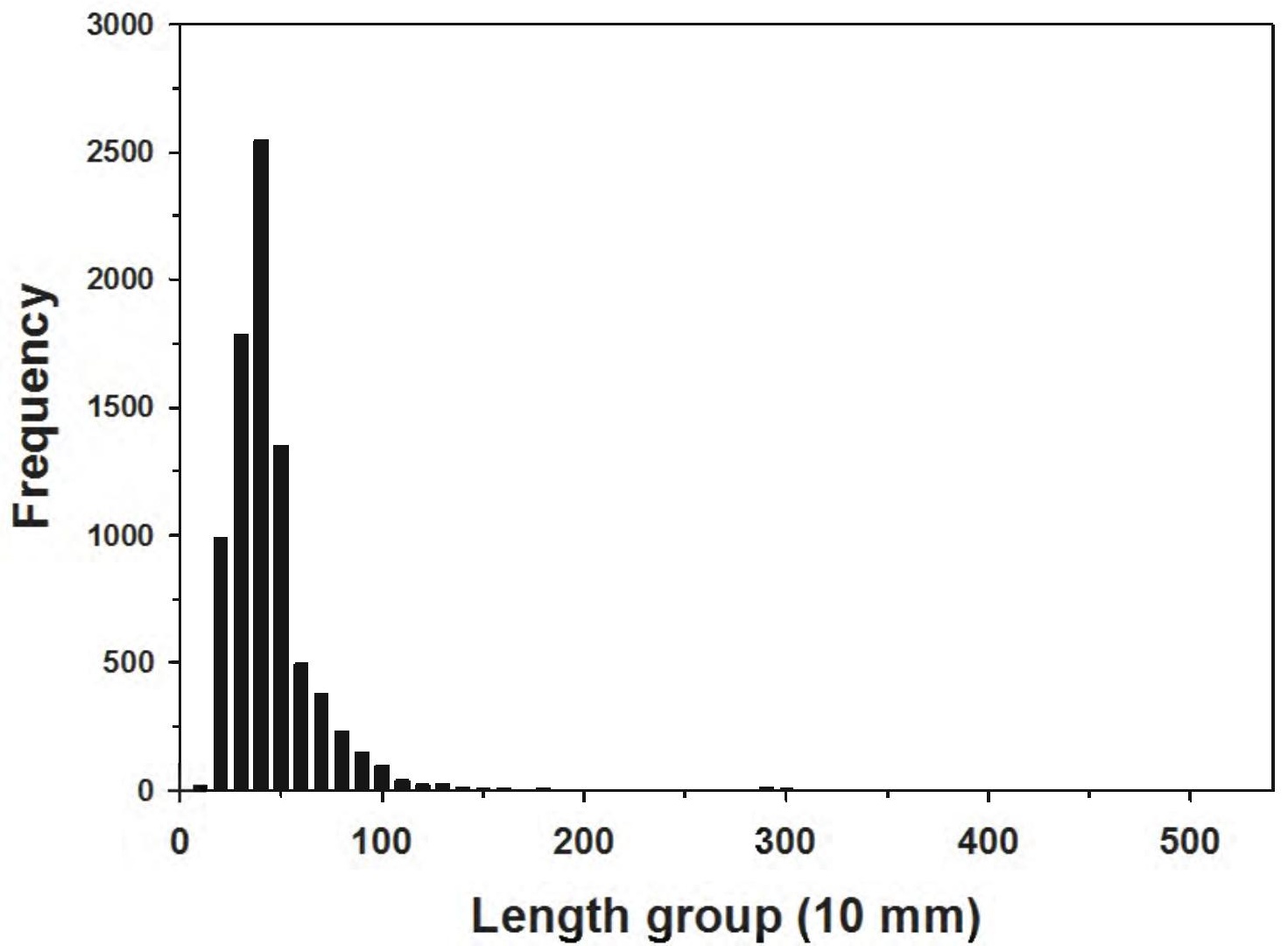




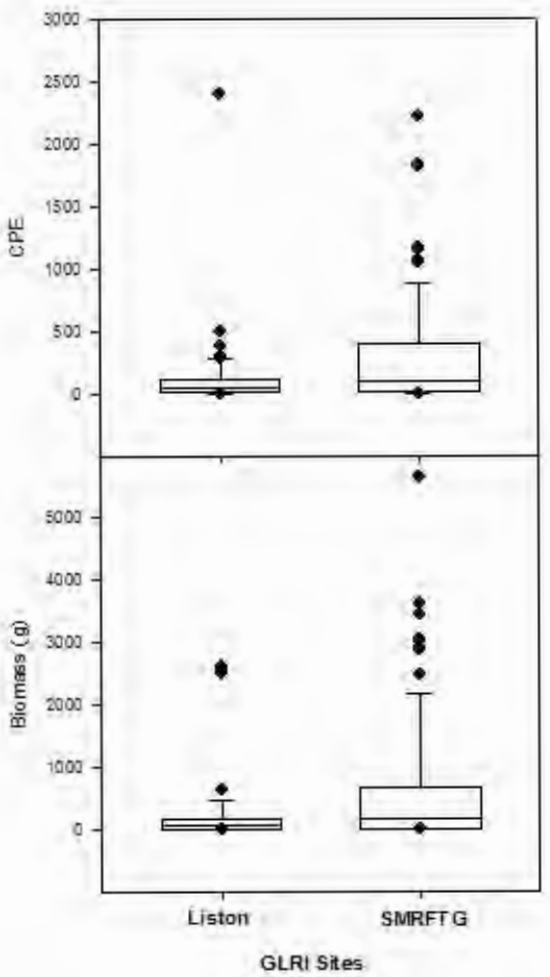




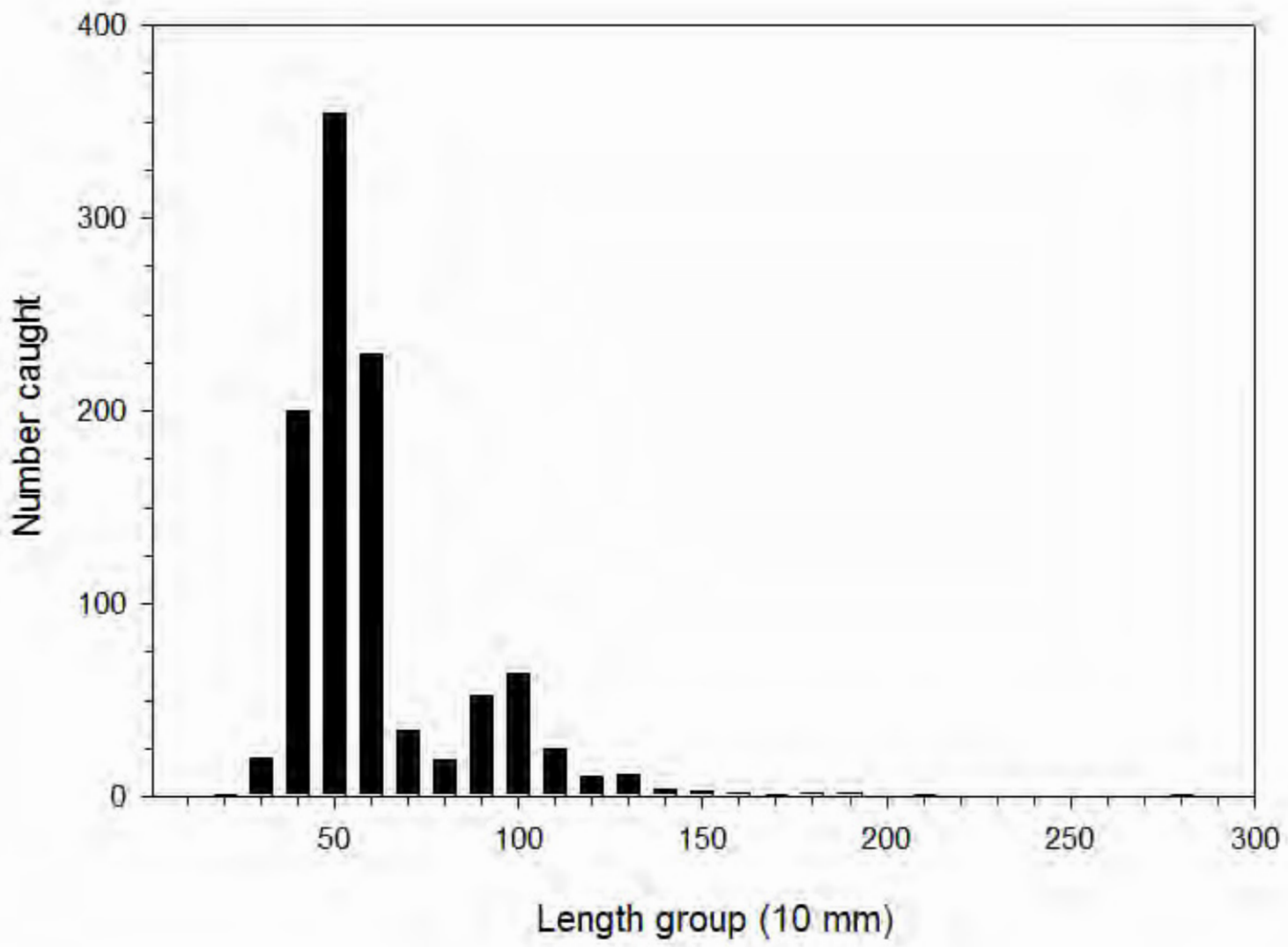

